PREPARED FOR THE U.S. DEPARTMENT OF ENERGY, UNDER CONTRACT DE-AC02-76CH03073

PPPL-3665

PPPL-3665

UC-70

Snowmass 2002: The Fusion Energy Sciences Summer Study

by

N. Sauthoff, G. Navratil, and R. Bangerter

January 2002

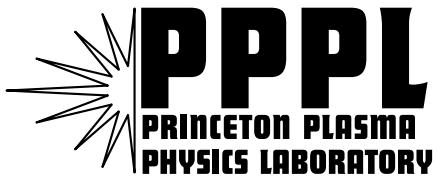

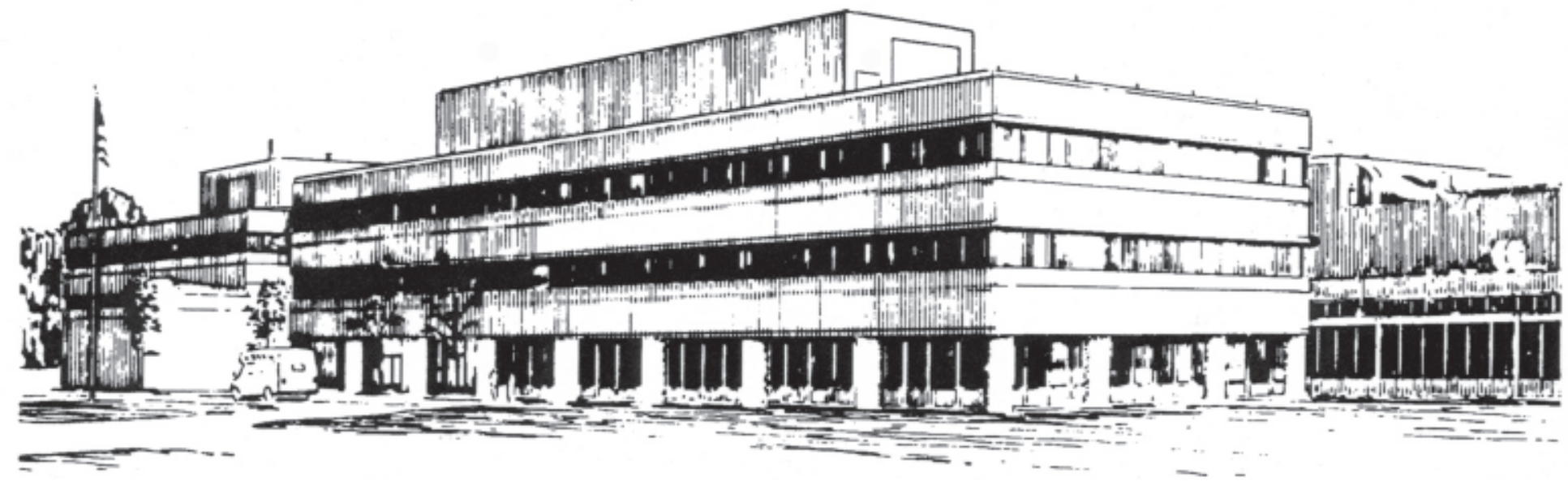

PRINCETON PLASMA PHYSICS LABORATORY PRINCETON UNIVERSITY, PRINCETON, NEW JERSEY 


\section{PPPL Reports Disclaimer}

This report was prepared as an account of work sponsored by an agency of the United States Government. Neither the United States Government nor any agency thereof, nor any of their employees, makes any warranty, express or implied, or assumes any legal liability or responsibility for the accuracy, completeness, or usefulness of any information, apparatus, product, or process disclosed, or represents that its use would not infringe privately owned rights. Reference herein to any specific commercial product, process, or service by trade name, trademark, manufacturer, or otherwise, does not necessarily constitute or imply its endorsement, recommendation, or favoring by the United States Government or any agency thereof. The views and opinions of authors expressed herein do not necessarily state or reflect those of the United States Government or any agency thereof.

\section{Availability}

This report is posted on the U.S. Department of Energy's Princeton Plasma Physics Laboratory Publications and Reports web site in Fiscal Year 2002. The home page for PPPL Reports and Publications is: http://www.pppl.gov/pub_report/

DOE and DOE Contractors can obtain copies of this report from:

U.S. Department of Energy

Office of Scientific and Technical Information

DOE Technical Information Services (DTIS)

P.O. Box 62

Oak Ridge, TN 37831

Telephone: (865) 576-8401

Fax: (865) 576-5728

Email: reports@adonis.osti.gov

This report is available to the general public from:

National Technical Information Service

U.S. Department of Commerce

5285 Port Royal Road

Springfield, VA 22161

Telephone: 1-800-553-6847 or

(703) 605-6000

Fax: (703) 321-8547

Internet: http://www.ntis.gov/ordering.htm 


\title{
Snowmass 2002: The Fusion Energy Sciences Summer Study
}

\author{
N. Sauthoff, DOE-Princeton Plasma Physics Laboratory; G. Navratil, Columbia University; and R. Bangerter, \\ Lawrence Berkeley National Laboratory
}

\begin{abstract}
The Fusion Summer Study 2002 will be a forum for the critical technical assessment of major next-steps in the fusion energy sciences program, and will provide crucial community input to the long-range planning activities undertaken by the DOE and the FESAC. It will be an ideal place for a broad community of scientists to examine goals and proposed initiatives in burning plasma science in magnetic fusion energy and integrated research experiments in inertial fusion energy. This meeting is open to every member of the fusion energy science community and significant international participation is encouraged. The objectives of the Fusion Summer Study are three:
\end{abstract}

1. Review scientific issues in burning plasmas to establish the basis for the following two objectives and to address the relations of burning plasma in tokamaks to innovative magnetic fusion energy (MFE) confinement concepts and of ignition in inertial fusion energy (IFE) to integrated research facilities.

2. Provide a forum for critical discussion and review of proposed MFE burning plasma experiments (e.g., IGNITOR, FIRE, and ITER) and assess the scientific and technological research opportunities and prospective benefits of these approaches to the study of burning plasmas.

3. Provide a forum for the IFE community to present plans for prospective integrated research facilities, assess present status of the technical base for each, and establish a timetable and technical progress necessary to proceed for each.

Based on significant preparatory work by the fusion community prior to the July Snowmass meeting, the Snowmass working groups will prepare a draft report that documents the scientific and technological benefits of studies of burning plasmas. The report will also include criteria by which the benefits of each approach to fusion science, fusion engineering/technology, and the fusion development path can be assessed. Finally, the report will present a uniform technical assessment of the benefits of the three approaches. The draft report will be presented and extensively discussed during the July meeting, leading to a final report. This report will provide critical fusion community input to the decision process of FESAC and DOE in 2002-2003, and to the review of burning plasma science by the National Academy of Sciences called for by FESAC and Energy Legislation which was passed by the House of Representatives [H. R. 4]. Members of the fusion community are encouraged to participate in the Snowmass working groups.

*Work supported by U.S. Department of energy under Contract \#DE-AC02-76CHO3073

\section{INTRODUCTION}

$\mathrm{T}$ HE 2002 Fusion Energy Sciences Summer Study, to be held in Snowmass, Colorado, in July 2002, is targeted at providing a forum for the critical uniform technical assessment of major next-steps in the fusion energy sciences program. It will provide crucial community input to the long range planning activities undertaken by the DOE and the FESAC regarding goals and proposed initiatives in burning plasma science in magnetic fusion energy, and integrated research *experiments in inertial fusion energy.

The scientific and technological views of the participants will provide critical fusion community inputs to

- the decision process of FESAC and DOE in 2002-2003, and

- the review of burning plasma science by the National Academy of Sciences called for by FESAC and Energy Legislation which was passed by the House of Representatives [H. R. 4].

The 2002 Summer Study builds on earlier planning activity at the 1999 Snowmass Fusion Summer Study and the scientific assessments at the UFA-sponsored Burning Plasma Science Workshops (Austin, Dec 2000; San Diego, May 2001). The Summer Study will be open to every member of the fusion energy science community, both MFE (tokamaks and other concepts) and IFE, and significant international participation is encouraged so that the study may gain the widest range of inputs.

\section{MAGNETIC FUSION ENERGY}

The goals of the MFE Objectives of the Fusion Summer Study include:

- refining the status of the MFE burning plasma basis and the research issues in both science and technology for both tokamaks and ICCs;

- providing a forum for critical discussion and review of proposed MFE burning plasma approaches/experiments (e.g., IGNITOR, FIRE, and ITER),

- uniformly assessing the scientific and technological research opportunities and prospective benefits of these approaches to the study of burning plasmas. (including developing uniform assessment criteria for science and technology issues including the relation of burning plasma in tokamaks to innovative MFE confinement concepts and 
assessing the risks and benefits of the different approaches to MFE burning plasma research)

_ providing the technical basis for decision-makers

Some key MFE issues to be considered at Snowmass include:

- critical burning plasma phenomena and experimental requirements for their study

- the scientific basis for proceeding with a burning plasma experiment: is now the time?

- how generic are burning plasma studies carried out in a tokamak?, and

- a uniform technical assessment of burning plasma experiment options.

The Snowmass MFE Study will feed into FESAC and NRC reviews by providing an expert consensus view on key issues:

- a clear articulation of the scientific basis for proceeding with a burning plasma experiment,

- identification of principal new physics phenomena and experimental requirements for their study, and

- a uniform technical assessment of approaches to burning plasma research.

The process for identifying MFE burning plasma issues and assessing related experiments is a structured interplay between scientific and technological experts in topical areas, and advocates for a range of approaches to studying burning plasmas. In the areas of physics, technology, and experimental approaches and options (commonly called "the rows"), the community will identify key scientific, technological and path issues, determine assessment criteria and perform uniform assessments of approaches. For each approach to burning plasmas (called "the rows"), advocates for FIRE, IGNITOR, and ITER will argue for scientific and technological benefits of their approaches. In addition, the Innovative Concept community will assess the benefits of a Tokamak burning plasma experiment to the development paths for innovative concepts.

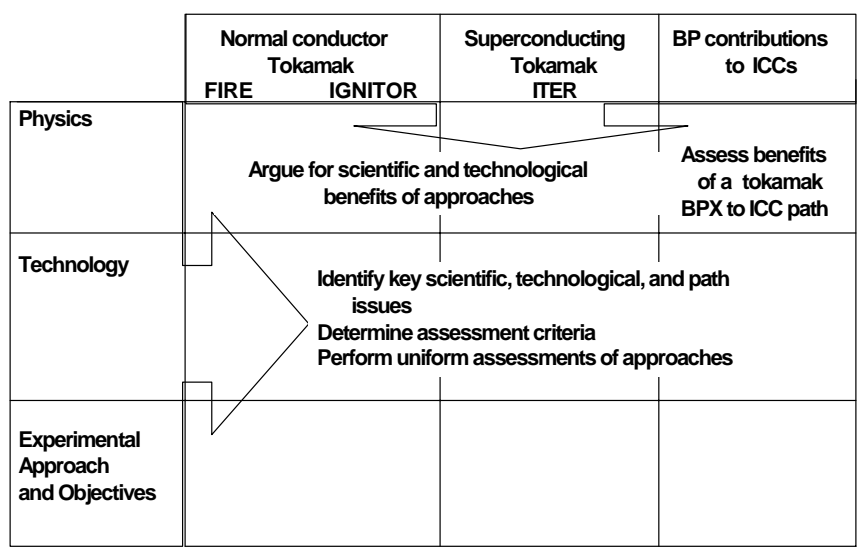

Fig. 1. Process for identifying MFE issues and assessment burning plasma experiments.
In each topical area (i.e., each "row"), the community will identify key issues, determine criteria for assessments of the approaches, and perform a uniform assessment. In each area, key topical areas have been identified and groups established.

\begin{tabular}{|c|c|c|}
\hline Physics & $\begin{array}{l}\text { Identify key scientific issues } \\
\text { Determine criteria for } \\
\quad \text { assessment of approaches } \\
\text { Perform uniform assessments } \\
\quad \text { of approaches }\end{array}$ & $\begin{array}{l}\text { Wave-Particle Interactions } \\
\text { MHD } \\
\text { Transport } \\
\text { Boundary Physics } \\
\text { Alpha Physics }\end{array}$ \\
\hline Technology & $\begin{array}{l}\text { Identify key technological } \\
\quad \text { issues and potential benefits } \\
\text { Determine criteria for } \\
\text { assessment of approaches } \\
\text { (feasibility, benefits, cost, } \\
\text { Perform uniform assessment }\end{array}$ & $\begin{array}{l}\text { Magnets } \\
\text { PFC/Heat removal } \\
\text { Heating/CD } \\
\text { Safety/Tritium/Materials } \\
\text { Vacuum Vessel/Remote } \\
\text { Cost }\end{array}$ \\
\hline $\begin{array}{l}\text { Experimental } \\
\text { Approach } \\
\text { and Objectives }\end{array}$ & $\begin{array}{l}\text { Identify integration, research } \\
\text { operations, development } \\
\text { path, and "community " } \\
\text { issues } \\
\text { Determine assessment criteria } \\
\text { Perform uniform assessment }\end{array}$ & \begin{tabular}{|l|} 
Diagnostics \\
Integrated Scenarios/ \\
Ignition Physics/Bum Control \\
Physics Operations \\
Development Path
\end{tabular} \\
\hline
\end{tabular}

Fig. 2. MFE topical group roles

The advocates for each approach to studying burning plasmas will provide information to the topical groups and will advocate their approaches. In addition, and as a key part of the Study, the Innovative Concept Community (ICC) will identify the key elements of the development path for ICCs and will assess the contributions of a burning tokamak plasma to the advancement of those elements.

\begin{tabular}{|c|c|c|}
\hline \begin{tabular}{l}
\multicolumn{2}{c}{ Normal conductor } \\
Tokamak \\
FIRE $\quad$ IGNITOR
\end{tabular} & $\begin{array}{c}\text { Superconducting } \\
\text { Tokamak } \\
\text { TER }\end{array}$ & $\begin{array}{c}\text { BP contributions } \\
\text { to ICCs }\end{array}$ \\
\hline \multicolumn{2}{|c|}{$\begin{array}{l}\text { Argue for scientific and technological } \\
\text { benefits of the approach: } \\
\text { - advocate scientific issues } \\
\text { - suggest physics "rules " and "guidelines " } \\
\text { - suggest assessment criteria } \\
\text { - participate in plasma performance } \\
\quad \text { simulations and resultant assessments, } \\
\quad \text { championing the case for each approach }\end{array}$} & $\begin{array}{l}\text { Assess benefits of } \\
\text { a tokamak BPX to } \\
\text { ICC path } \\
\text { - identify ICC } \\
\text { issues } \\
\text { (physics, } \\
\text { technology, } \\
\text { development } \\
\text { path) } \\
\text { - assess } \\
\text { applicability of } \\
\text { the tokamak } \\
\text { results on the } \\
\text { ICC } \\
\text { development }\end{array}$ \\
\hline
\end{tabular}

Fig. 3. Roles of the MFE approach advocates and the ICC community

In order to focus the study and to provide a structure for the output, a draft structure has been developed for the final report. The major outline elements include:

- $\quad$ Executive summary, integrating MFE and IFE [4 pages]

- Introduction, integrating MFE and IFE (goals, background)

- MFE burning plasma science and technology topics (intro, status, R\&D needs, plasma requirements to address/resolve R\&D needs)

- Approaches to MFE burning plasma studies, including 
relationship to ICCs, development paths, international context

- Key MFE scientific / technological / path issues, assessment criteria, and figures of merit

- Assessments of approaches to MFE burning plasmas

- MFE Appendices

- MFE Attachments

The body of the report is targeted at being short enough to be readable, but long enough to provide the necessary information for decision-makers. The appendices will include specific technical backup for the report, prepared by the working groups. The attachments will include contributions from the community.

\section{INERTIAL FUSION ENERGY}

IFE Objectives of the Fusion Summer Study include

- providing a forum for presenting plans for prospective integrated research facilities, assessing the present status of the technical base for each, and establishing a timetable and technical progress necessary to proceed for each); and

- addressing the relation of ignition in IFE to integrated research facilities.

The current IFE development strategy includes a sequence of stages of development, from concept exploration to fusion energy development, with associated increased cost and required confidence.

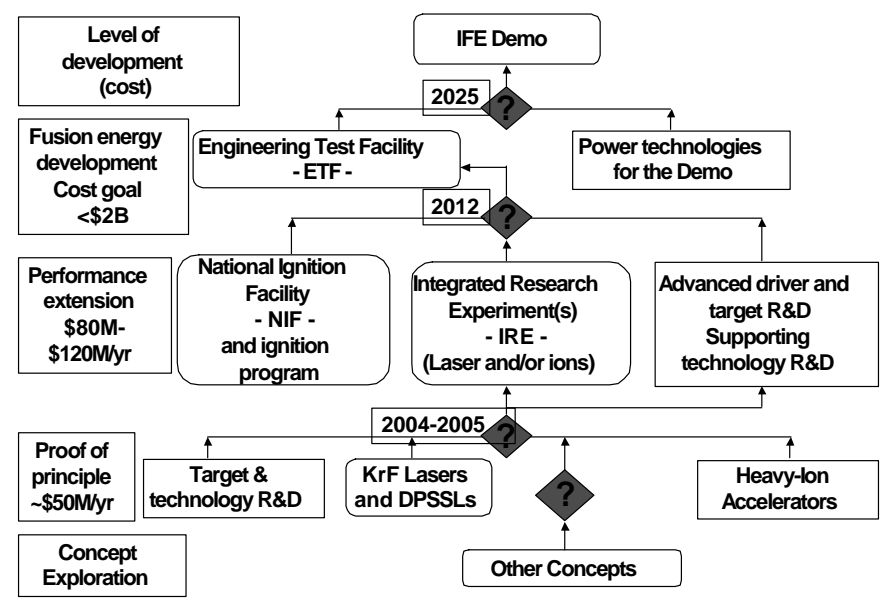

Fig. 4. The Inertial Fusion Energy Development Strategy

$\ddot{y}$ Provide the technical basis for decision-makers

The structure of the IFE organization involves scientific and technological topics ("rows") and driver physics and technology and next steps ("columns").

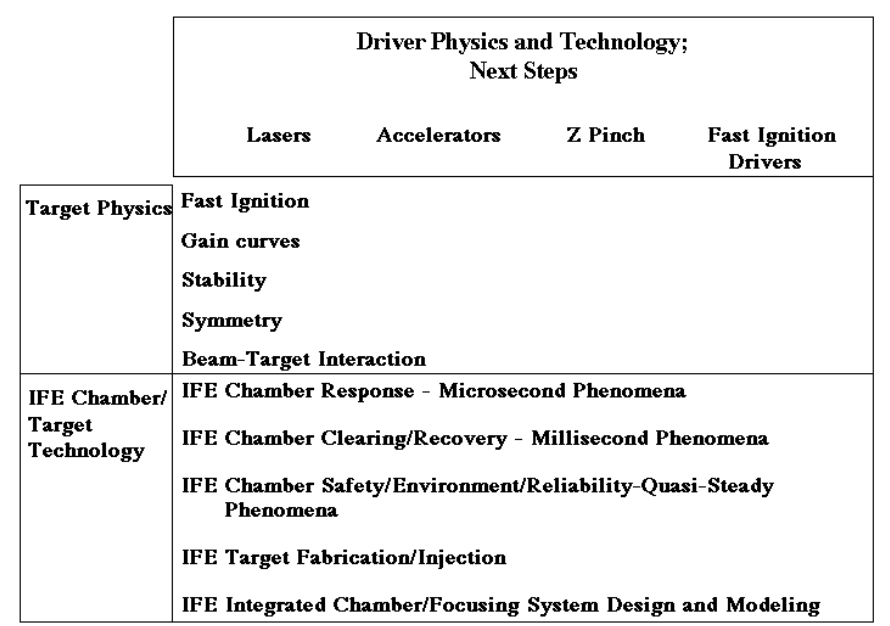

Fig. 5. Structure of the Inertial Fusion Energy study

\section{COMMUNITY ISSUES}

To address concerns and to acquire some non-technical inputs of the MFE and IFE communities, a Community Issues Group has been established to foster communication on non-technical issues. The group will discuss direction as a community, including visions of the nature of the science to be done, and how it fits with possible burning plasma experiments. The group will develop a contribution for the Snowmass report based on broad community input.

\section{NEAR-TERM PLASMAS}

To provide inputs to the July workshop sufficient to enable focus on and resolution of the really key issues, significant work must be performed well in advance of the workshop. In the December 2001-March 2002 period, key issues and criteria will be define, information on approaches will be gathered, tools will be prepared, and initial uniform assessments will be begun; in addition, those parts of the report that are not controversial and can be based on previous studies will be drafted. In the April-May 2002 period, the initial assessments will be discussed between the topical groups and the advocates of the approaches, refined assessments will be prepared, and the draft report will be completed. The draft report will be made available to the entire fusion community in early-June to enable more focused and informed study at Snowmass in July 2002. The output of the Summer Study will be presented to the Fusion Energy Sciences Advisory Committee in August, leading to a DOE recommendation of the preferred path for US study of burning plasmas. 


\section{External Distribution}

Plasma Research Laboratory, Australian National University, Australia

Professor I.R. J ones, Flinders University, Australia

Professor J oão Canalle, Instituto de Fisica DEQ/IF - UERJ , Brazil

Mr. Gerson O. Ludwig, Instituto Nacional de Pesquisas, Brazil

Dr. P.H. Sakanaka, Instituto Fisica, Brazil

The Librarian, Culham Laboratory, England

Library, R61, Rutherford Appleton Laboratory, England

Mrs. S.A. Hutchinson, JET Library, England

Professor M.N. Bussac, Ecole Polytechnique, France

Librarian, Max-Planck-Institut für Plasmaphysik, Germany

J olan Moldvai, Reports Library, MTA KFKI-ATKI, Hungary

Dr. P. Kaw, Institute for Plasma Research, India

Ms. P.J . Pathak, Librarian, Insitute for Plasma Research, India

Ms. Clelia De Palo, Associazione EURATOM-ENEA, I taly

Dr. G. Grosso, Instituto di Fisica del Plasma, Italy

Librarian, Naka Fusion Research Establishment, J AERI, J apan

Library, Plasma Physics Laboratory, Kyoto University, J apan

Research Information Center, National Institute for Fusion Science, J apan

Dr. O. Mitarai, Kyushu Tokai University, J apan

Library, Academia Sinica, Institute of Plasma Physics, People's Republic of China

Shih-Tung Tsai, Institute of Physics, Chinese Academy of Sciences, People's Republic of China

Dr. S. Mirnov, TRINITI, Troitsk, Russian Federation, Russia

Dr. V.S. Strelkov, Kurchatov Institute, Russian Federation, Russia

Professor Peter Lukac, Katedra Fyziky Plazmy MFF UK, Mlynska dolina F-2, Komenskeho Univerzita, SK-842 15 Bratislava, Slovakia

Dr. G.S. Lee, Korea Basic Science Institute, South Korea

Mr. Dennis Bruggink, Fusion Library, University of Wisconsin, USA

Institute for Plasma Research, University of Maryland, USA

Librarian, Fusion Energy Division, Oak Ridge National Laboratory, USA

Librarian, Institute of Fusion Studies, University of Texas, USA

Librarian, Magnetic Fusion Program, Lawrence Livermore National Laboratory, USA

Library, General Atomics, USA

Plasma Physics Group, Fusion Energy Research Program, University of California at San Diego, USA

Plasma Physics Library, Columbia University, USA

Alkesh Punjabi, Center for Fusion Research and Training, Hampton University, USA

Dr. W.M. Stacey, Fusion Research Center, Georgia Institute of Technology, USA

Dr. J ohn Willis, U.S. Department of Energy, Office of Fusion Energy Sciences, USA

Mr. Paul H. Wright, Indianapolis, Indiana, USA 
The Princeton Plasma Physics Laboratory is operated by Princeton University under contract with the U.S. Department of Energy.

\author{
Information Services \\ Princeton Plasma Physics Laboratory \\ P.O. Box 451 \\ Princeton, NJ 08543
}

Phone: 609-243-2750

Fax: 609-243-2751

e-mail: pppl_info@pppl.gov

Internet Address: http://www.pppl.gov 